\title{
The promotional effect of water-soluble extractives on the enzymatic cellulose hydrolysis of pretreated wheat straw
}

A.T. Smit

W.J.J. Huijgen

July 2017

ECN-W--17-007

Published in Elsevier Bioresource Technology Vol. 243 (2017) 994-999 


\title{
The promotional effect of water-soluble extractives on the enzymatic cellulose hydrolysis of pretreated wheat straw
}

\author{
A.T. Smit* ${ }^{*}$ W.J.J. Huijgen \\ Energy Research Centre of the Netherlands (ECN), Biomass \& Energy Efficiency, P.O. Box 1, 1755 ZG Petten, The Netherlands
}

\section{H I G H L I G H T S}

-Water-soluble extractives from wheat straw enhance enzymatic cellulose hydrolysis.

- Promotional effect from unpurified extract, no additional processing required.

- Possibly positive effect on enzyme deactivation and cellulose accessibility.

- Up to $85 \%$ relative increase in digestibility of organosolv pretreated pulp.

- Promotional effect caused by components larger than $1 \mathrm{kD}$, possibly proteins.

\section{A R T I C L E I N F O}

\section{Article history:}

Received 11 May 2017

Received in revised form 12 July 2017

Accepted 13 July 2017

Available online 15 July 2017

\section{Keywords:}

Cellulase

Enzyme deactivation

Organosolv

Protein

Pretreatment

\begin{abstract}
A B S T R A C T
Enzymatic cellulose hydrolysis of pretreated wheat straw pulp to glucose is enhanced when the hydrolysis is performed in the presence of an aqueous extract of the wheat straw. A relative digestibility increase of about $10 \%$ has been observed for organosolv, alkaline and dilute acid pretreated wheat straw pulp (enzyme dose $2.5 \mathrm{FPU} / \mathrm{g}$ pulp). At lower enzyme doses, the extract effect increases leading to an enzyme dose reduction of $40 \%$ to obtain a glucose yield of $75 \%$ within $48 \mathrm{~h}$ using organosolv wheat straw pulp. Possibly, cellulase deactivation by irreversible binding to pulp lignin is reduced by competition with proteins in the extract. However, since the extract effect has also been demonstrated for lignin-lean substrates, other effects like improved accessibility of the pulp cellulose (amorphogenesis) cannot be excluded. Overall, this contribution demonstrates the positive effect of biomass extractives on enzymatic cellulose digestibility, thereby reducing costs for $2 \mathrm{G}$ biofuels and bio-based chemicals.
\end{abstract}

(c) 2017 Elsevier Ltd. All rights reserved.

\section{Introduction}

The valorization of lignocellulose into bio-based platform chemicals and biofuels is one of the most important developments to meet concerns over global climate change and fossil fuel depletion. Efficient enzymatic conversion of (hemi)cellulose into monomeric sugars is one of the major challenges for an economically feasible lignocellulosic biorefinery (Wyman, 2007; KleinMarcuschamer et al., 2012). The highly crystalline fibrillary structure of the cellulose encased in a matrix of lignin and hemicellulose renders it resistant to enzymatic depolymerization. Therefore, pretreatment of lignocellulosic biomass is required to increase the accessibility of the cellulose for (hemi)cellulolytic enzymes (Park et al., 2010; Hall et al., 2010). Lignin removal or redistribution is one of the most important factors for improving the accessibility,

\footnotetext{
* Corresponding author.

E-mail address: a.t.smit@ecn.nl (A.T. Smit).
}

enhancing the hydrolysis rate and sugar yield (Van Dyk and Pletschke, 2012; Mansfield et al., 1999).

Residual lignin in pretreated biomass can negatively affect enzymatic hydrolysis by reducing enzyme activity due to nonproductive binding of enzymes to its surface (Gao et al., 2014; Varnai et al., 2010; Yang and Pan, 2016). Several possible measures have been reported for minimizing enzyme deactivation by nonproductive adsorption to lignin including addition of surfactants such as polyethylene glycol (Kristensen et al., 2007; Borjesson et al., 2007), Tween 20 (Zheng et al., 2008), Tween 80 (Tu and Saddler, 2010), metal ions (Akimkulova et al., 2016), and proteins such as the model protein BSA (Yang and Wyman, 2006; Pan et al., 2005; Brethauer et al., 2011) or biomass proteins (Han and Chen, 2007, 2010). Addition of non-hydrolytic proteins may not only minimize enzyme deactivation, but could possibly also loosen the highly ordered and tightly packed regions of the cellulose by amorphogenesis leading to increased access of cellulase enzymes to the cellulose (Arantes and Saddler, 2010; Han and Chen, 2007; 


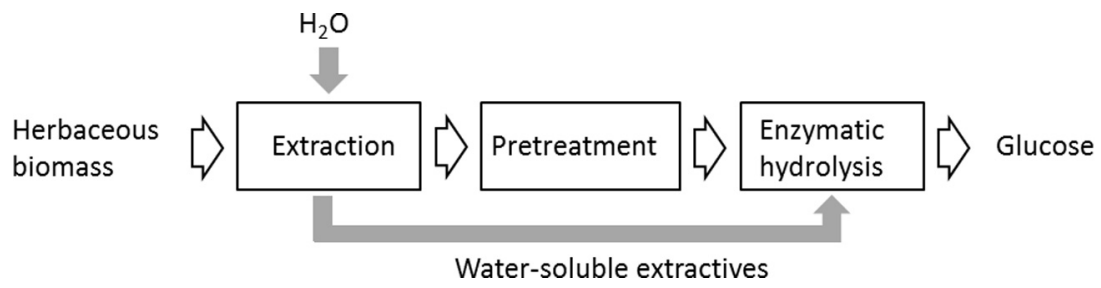

Fig. 1. Schematic representation of the process.

Coughlan, 1985). Han and Chen (2007) isolated a non-hydrolytic protein (Zea h) from fresh postharvest corn stover which was found to increase the cellulose hydrolysis rate and glucose yield substantially. However, the use of purified proteins is costly, which might negate the overall net cost savings generated by the lower enzyme dosage requirements.

In this study, we examined the effect of adding an unpurified protein-containing aqueous extract of biomass directly to the enzymatic saccharification of pretreated biomass pulp (Fig. 1). Extraction prior to pretreatment prevents the degradation of proteins caused by the high severity generally used for pretreatment of biomass. In this study, we explore whether similar effects as reported with purified proteins can be obtained with an unpurified extract in spite of possible inhibiting effects of matrix components such as salts. This paper focuses on EtOH organosolv, dilute acid and alkaline pretreatment of wheat straw. For various other combinations of herbaceous feedstocks, pretreatment processes and extracts tested, we refer to Smit and Huijgen (2014) and the Supporting Information.

\section{Materials and methods}

\subsection{Materials}

For compositional analysis the following chemicals were used: $\mathrm{H}_{2} \mathrm{SO}_{4}$ from Boom $72 \%$ p.a, $\mathrm{BaCO}_{3}$ (Merck, EMSURE ${ }^{\circledR}$ ACS grade), and the sugar standards glucose (Sigma >99.5\%), xylose (Fluka $>98 \%$ ), mannose, arabinose, galactose and rhamnose monohydrate (all Fluka, HPLC grade, >99\%).

Ethanol $96 \% \mathrm{v} / \mathrm{v}$ was obtained from Nedalco, sodium azide 99.5\%, sulfuric acid 98\%, sodium hydroxide 98\% from Sigma, sodium acetate trihydrate and glacial acetic acid 100\% from Merck, o-toluidine 99\% from Aldrich, Avicel PH-101, thiourea 99\% and sodium chlorite $80 \%$ from Sigma-Aldrich and Pierce ${ }^{\mathrm{TM}}$ BCA protein assay kit from Thermo Scientific. The commercial enzyme mixtures Accellerase TRIO and 1500 were obtained from DuPont Industrial Biosciences (Leiden, NL) for (hemi)cellulose hydrolysis. Wheat straw was grown and harvested in 2013 in The Netherlands.

\subsection{Biomass pretreatment}

Ambient dry wheat straw was cut using a Retsch SM2000 cutter mill equipped with a $1 \mathrm{~cm}$ sieve. The moisture content of the straw was determined using a halogen moisture analyzer (Mettler Toledo HR83, Columbus, OH). $1.5 \mathrm{~kg}$ of wheat straw (moisture content
$11.5 \% \mathrm{w} / \mathrm{w}$ ) was placed in a glass pipe fitted with an $185 \mu \mathrm{m}$ filter supported by a glass frit. $2 \mathrm{~kg}$ of demineralized water $\left(50{ }^{\circ} \mathrm{C}\right)$ was added and the sample was heated in a convection oven at $50{ }^{\circ} \mathrm{C}$ for $60 \mathrm{~min}$. The glass pipe was placed in vertical position and demineralized water $\left(50^{\circ} \mathrm{C}\right)$ was added to the top until 2 parts by weight of extract was obtained per part of dry weight straw from the bottom (i.e., $3 \mathrm{~kg}$ ). A subsample of the extract was concentrated using a $1 \mathrm{kD}$ Pall Minimate ultrafiltration module. The extract, concentrate and filtrate were preserved with sodium azide $(0.02 \% \mathrm{w} / \mathrm{v}$ final concentration) and stored at $4{ }^{\circ} \mathrm{C}$.

Organosolv pretreatment was performed (Table 1) with the wet extracted straw (moisture content $75.0 \% \mathrm{w} / \mathrm{w}$ ) in an autoclave reactor (20 L Kiloclave, Büchi Glas Uster AG, Switzerland) using conditions based on earlier work (Wildschut et al., 2013). A mixture of extracted straw, $60 \%(\mathrm{w} / \mathrm{w})$ aqueous ethanol (taking into account the straw moisture content) and $24 \mathrm{mM}$ sulfuric acid (liquid/solid ratio of $10 \mathrm{~L} / \mathrm{kg}$ dry weight extracted straw) was heated to $190{ }^{\circ} \mathrm{C}$ and kept isothermal for $60 \mathrm{~min}$ while stirring with an anchor stirrer at $500 \mathrm{rpm}$. After cooling below $25^{\circ} \mathrm{C}$, the slurry was measured for $\mathrm{pH}$ and filtered over a Whatman GF/D filter. The solids were first washed with $60 \% \mathrm{w} / \mathrm{w}$ aqueous ethanol $(5 \mathrm{~L} /$ $\mathrm{kg}$ initial dry weight straw) followed by a wash with water to remove ethanol from the solids. A subsample was dried at $50{ }^{\circ} \mathrm{C}$ to determine pulp yield, moisture content and composition. $550 \mathrm{~g}$ of wet pulp (100 g dry weight) was bleached with $10 \mathrm{~g}$ of sodium chlorite and $6.6 \mathrm{~mL}$ glacial acetic acid in $1.5 \mathrm{~L}$ of demineralized water at $70{ }^{\circ} \mathrm{C}$ while stirring. The pulp was filtered over a $256 \mathrm{~mm}$ Whatman GF/D filter and the bleaching step repeated twice to a total of 3 . The bleached pulp was extensively washed with demineralized water and stored at $4{ }^{\circ} \mathrm{C}$.

Similar to the above mentioned extraction, extraction at smaller scale was performed on wheat straw cut to $<4 \mathrm{~mm}$. The filtrate was preserved with sodium azide and stored at $4{ }^{\circ} \mathrm{C}$ without a concentration step. Smaller scale dilute acid and alkaline pretreatments with the extracted straw were performed in $125 \mathrm{~mL}$ batch reactors (acid digestion bomb type 4748, SS 316 with Teflon liner, Parr Instrument Company, Moline, IL) as described in Table $1.23 .3 \mathrm{~g}$ ( $6 \mathrm{~g}$ dry weight) extracted wet straw was mixed with water and catalyst to a final liquid/solid ratio of $10 \mathrm{~L} / \mathrm{kg}$ dry weight extracted straw. The batch reactors were placed in a heating block for $180 \mathrm{~min}$ (roughly equals a time on target temperature of $60 \mathrm{~min}$, see Huijgen et al. (2011)), while being stirred using a magnetic bar $(500 \mathrm{rpm})$. The solids were recovered by filtration, washed with water $\left(10 \mathrm{~L} / \mathrm{kg}\right.$ initial dry weight straw) and stored at $4{ }^{\circ} \mathrm{C}$. A subsample was dried at $50^{\circ} \mathrm{C}$ to determine pulp yield, moisture content and composition.

Table 1

Substrates: applied pretreatment processes.

\begin{tabular}{|c|c|c|c|c|c|}
\hline Substrate code & Pretreatment & $\mathrm{T}\left({ }^{\circ} \mathrm{C}\right)$ & $\mathrm{t}(\mathrm{min})$ & Solvent & Catalyst \\
\hline OS-190 & Organosolv & 190 & 60 & $60 \% \mathrm{w} / \mathrm{w}$ aqueous ethanol & $24 \mathrm{mM} \mathrm{H}_{2} \mathrm{SO}_{4}$ \\
\hline DA-140 & Dilute acid & 140 & 60 & Water & $80 \mathrm{mM} \mathrm{H}_{2} \mathrm{SO}_{4}$ \\
\hline DA-160 & & 160 & 60 & Water & $40 \mathrm{mM} \mathrm{H}_{2} \mathrm{SO}_{4}$ \\
\hline DA-180 & & 180 & 60 & Water & $20 \mathrm{mM} \mathrm{H}_{2} \mathrm{SO}_{4}$ \\
\hline AL-121 & Alkaline & 121 & 60 & Water & $2.5 \mathrm{wt} \% \mathrm{NaOH}$ \\
\hline
\end{tabular}




\subsection{Lignocellulose composition analysis}

The summative composition of wheat straw and pulps was analyzed using procedures described in earlier work (Wildschut et al., 2013). These procedures are modified versions of the NREL standard biomass analytical procedures (National Renewable Energy Laboratory (NREL), 2009). In short, the content of lignin, hemicelluloses, and cellulose was determined in duplicate by hydrolysis (for wheat straw, extractives were removed first with two successive Soxhlet extractions using water and ethanol (NREL/TP-51042619)). The sample was milled with a cutting mill and hydrolyzed in two steps: (1) $12 \mathrm{M}(72 \% \mathrm{w} / \mathrm{w}) \mathrm{H}_{2} \mathrm{SO}_{4}\left(30^{\circ} \mathrm{C}, 1 \mathrm{~h}\right)$ and (2) $1.2 \mathrm{M}$ $\mathrm{H}_{2} \mathrm{SO}_{4}\left(100{ }^{\circ} \mathrm{C}, 3 \mathrm{~h}\right)$. The solid residue was determined gravimetrically and its ash content was measured. The acid-insoluble lignin (AIL) content was based on the amount of ash-free residue. Finally, the hydrolysate was analyzed for monomeric sugars using HPAECPAD and acid-soluble lignin (ASL) using UV-VIS absorption. The elemental composition ( $\mathrm{C}, \mathrm{H}, \mathrm{N}$, and $\mathrm{O}$ ) of wheat straw was measured with an elemental analyzer (Carlo Erba Instruments FLASHEA1112, Wigan, UK).

\subsection{Enzymatic hydrolysis}

Enzymatic hydrolysis was performed at $50^{\circ} \mathrm{C}$ for $72 \mathrm{~h}$ on a rotary shaker at $140 \mathrm{rpm}$ with $0.05 \mathrm{M}$ sodium citrate buffer $(\mathrm{pH}$ 5.0 ) and $0.02 \% \mathrm{w} / \mathrm{v}$ sodium azide. $5 \mathrm{~g}$ (dry weight) of wet pretreated material was added per $50 \mathrm{~mL}$ hydrolysis liquid according to NREL/TP-510-42629. The commercial enzyme mixture Accellerase TRIO (DuPont Industrial Biosciences, Leiden, NL) was used for (hemi)cellulose hydrolysis. The enzyme activity of the Accellerase TRIO batch used was $33 \mathrm{FPU} / \mathrm{mL}$ and $2103 \mathrm{CMC} \mathrm{U} / \mathrm{mL}$, determined according to Ghose (1987). After 0, 6, 24, 48 and 72 h samples were taken for colorimetric determination of the glucose concentration (Yee and Goodwin, 1973). In short, $2 \mathrm{~mL}$ of reagent ( $9 \% \mathrm{v} / \mathrm{v}$ otoluidine, $1.5 \% \mathrm{w} / \mathrm{v}$ thiourea in glacial acetic acid) was added to $20 \mu$ l of (diluted) sample and heated in a water bath to $90{ }^{\circ} \mathrm{C}$ for $8 \mathrm{~min}$. After cooling in tap water for $4 \mathrm{~min}$ the absorbance was measured at $635 \mathrm{~nm}$. Glucose yield is expressed as percentage of the pulp glucan converted to glucose.

The amount of extract added to the hydrolysis, replacing demineralized water, was set at the maximum allowed by the feedstock used. This maximum was calculated using the formula: extract dose $(\mathrm{g})=($ substrate used $(\mathrm{g}$ dry weight)/pulp yield (incl. extraction) $)^{*}$ weight percentage extract obtained per part of the feedstock.

\subsection{Protein assay}

Protein concentrations were determined with bicinchoninic acid as coloring agent using the BCA protein assay kit (see Sec- tion 2.1). Because the reagent also reacts to some degree with other extract components, the absorbance of the extract was corrected for the absorbance of the protein-free extract resulting from the $1 \mathrm{kD}$ ultrafiltration. Protein concentration in the cellulase cocktail was measured directly.

\section{Results and discussion}

\subsection{Biomass pretreatment}

Table 2 shows the composition of the wheat straw used and the (bleached) pulps obtained from the applied pretreatment processes. All the percentages presented in this section are expressed as $\% \mathrm{w} / \mathrm{w}$ (on dry basis). Protein content of the wheat straw used was $2.9 \%$ determined by $\mathrm{N}$-content $\times 6.25$. Extraction of the wheat straw prior to organosolv fractionation removed $4.9 \%$ of the initial wheat straw as extractives (including soluble minerals). From the total amount of proteins present in the wheat straw $21.5 \%$ was removed resulting in a protein concentration in the extract of $2.7 \mathrm{~g} / 1$.

Wheat straw fractionation using organosolv pretreatment solubilizes most of the hemicellulose and lignin. As a result, the solid pulp after fractionation is enriched in cellulose with an increased accessibility to cellulases. The optimum wheat straw fractionation conditions using an acid-catalyzed ethanol-based organosolv (Table 1) were selected from Wildschut et al. (2013). Preextraction and subsequent organosolv pretreatment of wheat straw resulted in a $95.5 \%$ removal of hemicellulose sugars, a delignification of $72.3 \%$ and a glucan recovery of $95.4 \%$. Bleaching the pulp removed $55.8 \%$ of the residual lignin in the pulp resulting in an overall delignification of the wheat straw of $84.5 \%$.

Wheat straw fractionation using dilute acid pretreatment results in effective hemicellulose removal. Lignin does not dissolve in the acidic aqueous liquid but its characteristics are altered by depolymerization, condensation and relocation (Trajano et al., 2013). Fractionation conditions for the dilute acid pretreatments were selected to obtain a similar level of wheat straw fractionation with possible differences in pulp (pseudo-) lignin characteristics. It was hypothesized that pretreatment at low temperature could yield a pulp with less-condensed lignin and thus a higher affinity for cellulase adsorption, possibly enhancing the positive effect of adding extractives to the enzymatic hydrolysis of the pulp. Extraction of the wheat straw used for the dilute acid and alkaline pretreatment experiments removed $4.6 \%$ as extractives. Pulp yield (including extraction) from the dilute acid pretreatment at $140{ }^{\circ} \mathrm{C} / 80 \mathrm{mM} \mathrm{H}_{2} \mathrm{SO}_{4}, 160{ }^{\circ} \mathrm{C} / 40 \mathrm{mM} \mathrm{H}_{2} \mathrm{SO}_{4}$ and $180^{\circ} \mathrm{C} / 20 \mathrm{mM}$ $\mathrm{H}_{2} \mathrm{SO}_{4}$ was $62.1,62.5$ and $63.3 \%$ respectively. The selected fractionation conditions resulted in a similar degree of hemicellulose removal and lignin content of the pulp. The lignin recovery in the pulp was 109,115 and $116 \%$ for the dilute acid pretreatment at

Table 2

Feedstock and pulp composition.

\begin{tabular}{|c|c|c|c|c|c|c|c|c|c|}
\hline \multirow[t]{2}{*}{ (\% dry weight) } & \multirow[t]{2}{*}{ Extractives $^{\mathrm{a}}$} & \multicolumn{4}{|c|}{ Carbohydrates } & \multicolumn{2}{|l|}{ Lignin } & \multirow[t]{2}{*}{ Ash } & \multirow[t]{2}{*}{ Sum } \\
\hline & & Glucan & Xylan & Arabinan & Galactan & AIL & ASL & & \\
\hline Wheat straw & 7.8 & $29.8 \pm 2.4$ & $20.6 \pm 1.7$ & $2.0 \pm 0.2$ & $0.7 \pm 0.1$ & $14.4 \pm 0.1$ & $1.2 \pm 0.0$ & $13.7 \pm 0.0$ & 92.6 \\
\hline Pulp OS-190 & $N A^{b}$ & $59.2 \pm 0.9$ & $2.0 \pm 0.0$ & $<\mathrm{DTL}^{\mathrm{c}}$ & $<\mathrm{DTL}$ & $8.7 \pm 0.4$ & $0.3 \pm 0.0$ & $23.9 \pm 0.0$ & 94.1 \\
\hline Bleached pulp OS-190 & NA & $64.1 \pm 1.3$ & $1.9 \pm 0.1$ & $<$ DTL & $<$ DTL & $4.1 \pm 0.2$ & $0.3 \pm 0.0$ & $23.4 \pm 0.1$ & 93.8 \\
\hline Pulp DA-140 & NA & $48.1 \pm 0.1$ & $2.7 \pm 0.0$ & $0.1 \pm 0.2$ & $0.3 \pm 0.0$ & $27.2 \pm 0.2$ & $0.9 \pm 0.0$ & $15.3 \pm 0.7$ & 94.0 \\
\hline Pulp DA-160 & NA & $47.2 \pm 0.7$ & $2.4 \pm 0.0$ & $<\mathrm{DTL}$ & $0.3 \pm 0.1$ & $28.6 \pm 1.3$ & $1.0 \pm 0.0$ & $13.9 \pm 0.2$ & 92.2 \\
\hline Pulp DA-180 & NA & $47.4 \pm 0.3$ & $2.5 \pm 0.1$ & $<\mathrm{DTL}$ & $0.3 \pm 0.0$ & $28.5 \pm 0.2$ & $1.0 \pm 0.0$ & $14.1 \pm 1.0$ & 94.0 \\
\hline Pulp AL-121 & NA & $54.5 \pm 0.1$ & $23.1 \pm 0.1$ & $2.1 \pm 0.1$ & $0.5 \pm 0.0$ & $5.9 \pm 0.2$ & $0.9 \pm 0.0$ & $2.2 \pm 0.4$ & 89.3 \\
\hline
\end{tabular}

${ }^{a} \mathrm{H}_{2} \mathrm{O}$ and ethanol extractives combined, corrected for soluble ash.

b NA: not applicable.

c <DTL: below detection limit. 
$140, \quad 160$ and $180^{\circ} \mathrm{C}$ respectively, suggesting pseudo-lignin formation.

Alkaline pretreatment solubilizes most of the lignin as well as a part of the hemicellulose fraction depending on reaction severity (McIntosh and Vancov, 2011). One set of conditions was selected without optimizing reaction conditions for optimal pulp digestibility. The pretreatment resulted in a pulp yield (including extraction) of $51.7 \%$ and a delignification of $77.5 \%$.

\subsection{Enzymatic hydrolysis}

3.2.1. Wheat straw pulp from ethanol-based organosolv pretreatment

The enzymatic digestibility of pulp obtained from organosolv pretreatment of wheat straw is presented in Fig. 2. Using an enzyme dose of $5.0 \mathrm{FPU} / \mathrm{g}$, there is sufficient cellulase activity to reach full cellulose conversion to glucose within $72 \mathrm{~h}$. A plateau is observed after $48 \mathrm{~h}$ when all the pulp cellulose has been hydrolyzed to monomeric glucose. The o-toluidine colorimetric assay slightly overestimates sugar concentrations as compared to HPLC sugar analysis (Huijgen et al., 2010) causing the glucose yield to exceed $100 \%$ when all pulp glucan has been converted to glucose. At lower enzyme doses, there is insufficient enzyme activity to reach full pulp cellulose conversion within $72 \mathrm{~h}$.

Addition of wheat straw extract as described in Section 2.4 increases the initial hydrolysis rate slightly (enzyme dose $5.0 \mathrm{FPU} / \mathrm{g}$ ) before reaching a plateau after $48 \mathrm{~h}$. For $2.5 \mathrm{FPU} / \mathrm{g}$, extract addition resulted in a $10.1 \%$ relative increase in glucose yield after $72 \mathrm{~h}$. The positive effect further increases at lower enzyme doses up to $84.8 \%$ relative increase in glucose yield at $0.5 \mathrm{FPU} / \mathrm{g}$. The reduction in enzyme dose required to reach a specific glucose yield was determined by plotting the glucose yield after $48 \mathrm{~h}$ of incubation against the applied enzyme dose. Addition of the extract reduces the enzyme dose with $26 \%$ to obtain a $90 \%$ glucose yield and with $40 \%$ to obtain a $75 \%$ glucose yield after $48 \mathrm{~h}$. As discussed in the introduction, possibly irreversible binding of enzymes to residual lignin in the pulp leads to deactivation of these enzymes. Addition of proteins or other components solubilized in the extract would decrease the deactivation by the mechanism of competition.

However, addition of the extract was also found to promote enzymatic hydrolysis when the substrate was further delignified by bleaching the pulp (Fig. 2) or using Avicel as substrate. In the latter case, using an enzyme dose of $5.0 \mathrm{FPU} / \mathrm{g}$, a glucose yield of $47.8 \%$ increased to $50.4 \%$ when the extract was added. Overall, it seems that decreased enzyme deactivation, enhanced pulp
Table 3

Control experiments.

\begin{tabular}{lllll}
\hline Entry & Substrate $^{1}$ & Cellulase & Extract & Glucose yield (\%) \\
\hline 1 & Yes & No & No & 0.0 \\
2 & Yes & Yes $^{2}$ & No & 48.0 \\
3 & Yes & No & Yes & 0.2 \\
4 & No & Yes $^{3}$ & Yes & $0.3^{4}$ \\
5 & Yes & Yes $^{2}$ & Yes & 72.2 \\
\hline
\end{tabular}

1 Pulp OS-190.

$21.0 \mathrm{FPU} / \mathrm{g}$.

$35.0 \mathrm{FPU} / \mathrm{g}$

${ }^{4}$ Glucose concentration converted to theoretical increase in OS-190 glucose yield.

accessibility by amorphogenesis as described by Arantes and Saddler (2010) and possibly also other effects play a role.

A series of control experiments was performed to exclude the possibility that (polymeric) sugars or any cellulase activity was present in the extract (Table 3). Using an enzyme dose of $1.0 \mathrm{FPU} / \mathrm{g}$, the added extract increases the organosolv pulp glucose yield with 24.2 absolute percentage points (entry 2 and 5). The control experiments presented in Table 3 show that the extract itself does neither contain cellulytic activity nor significant concentrations of (polymeric) glucose (entry 3 ). In addition, no glucose was detected in the cellulase mixture used (entry 4). Finally, no glucose was released from the pulp when no cellulase was added (entry 1).

Subsequently, the extract was filtered over an $1 \mathrm{kD}$ ultrafiltration membrane. Addition of the filtrate (fraction $<1 \mathrm{kD}$ ) resulted in a negligible extra conversion of organosolv pulp glucan of $0.2 \%$ as compared to an increase of $10.2 \%$ absolute (10.1\% relative) percentage points using a whole extract at an enzyme dose of $2.5 \mathrm{FPU} /$ g. Therefore, we conclude that the extract effects are the result from components larger than $1 \mathrm{kD}$, possibly proteins.

A third set of experiments was performed to assess how the effect of the extract compares to the effect of bovine serum albumin (BSA) addition. Secondly, the extract dose was increased to determine the maximum promotional effect of wheat straw extractives on the cellulose digestibility of organosolv pretreated wheat straw. It is important to note that the extraction of wheat straw cannot supply enough proteins needed for the studied increase in extract dose. For example, $5 \mathrm{~g}$ of organosolv pulp originated from $10.4 \mathrm{~g}$ of wheat straw (47.9\% pretreatment pulp yield incl. extractions). $20.8 \mathrm{~g}$ of extract was obtained from wheat straw extraction with a protein concentration of $2.7 \mathrm{~g} / \mathrm{l}$. Thus, total
Pulp

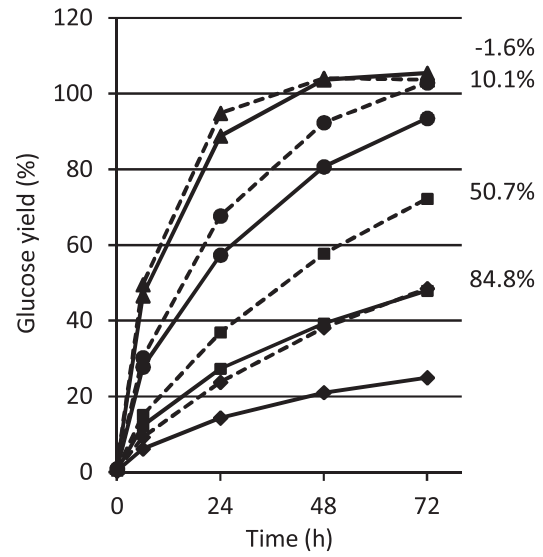

Bleached pulp

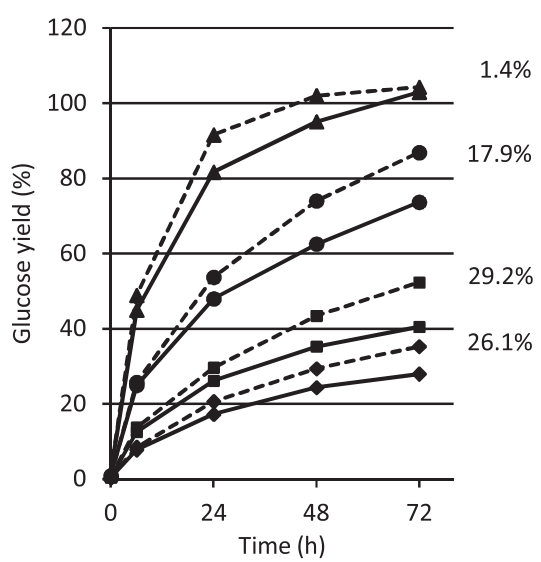

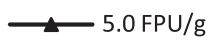

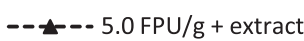

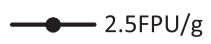

$---2.5 \mathrm{FPU} / \mathrm{g}+$ extract

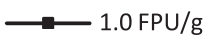

$---2-0 \mathrm{FPU} / \mathrm{g}+$ extract

$\longrightarrow 0.5 \mathrm{FPU} / \mathrm{g}$

--ャ-- $0.5 \mathrm{FPU} / \mathrm{g}+$ extract

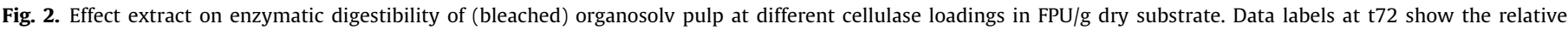
increase in glucose yield when extract is added. 


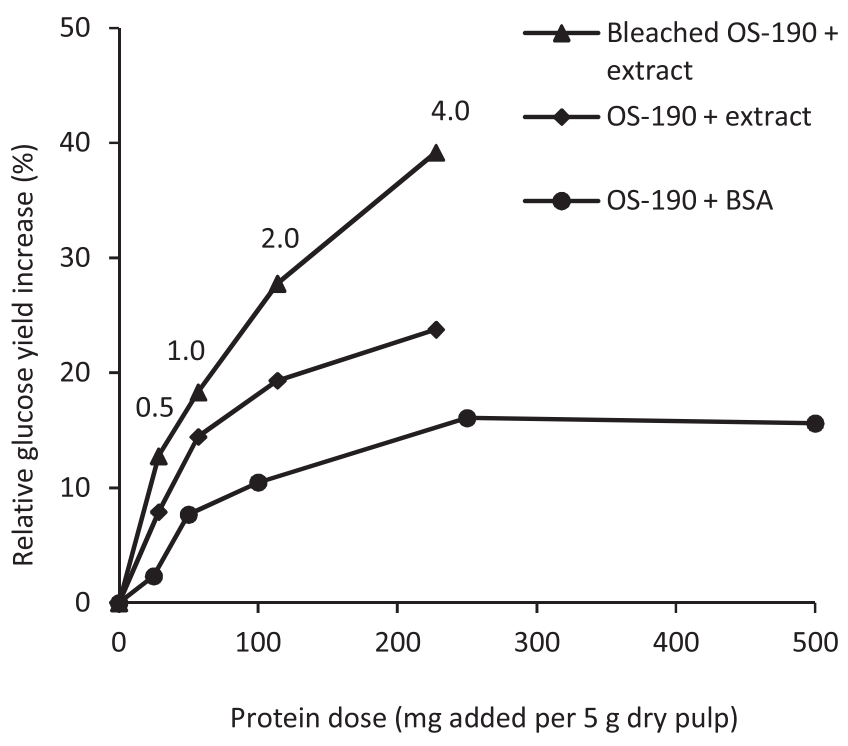

Fig. 3. Effect protein and extract addition on enzymatic digestibility after $48 \mathrm{~h}$ using $2.5 \mathrm{FPU} / \mathrm{g}$ dry substrate. Data labels show the extract dose where 1.0 is the maximum that can be obtained from the feedstock (see Section 2.4).

protein yield is $56 \mathrm{mg}$ (data label 1.0 in Fig. 3). The extract, concentrated over a $1 \mathrm{kD}$ ultrafiltration module, was added to the (bleached) pulp at different doses expressed in mg protein added per $5 \mathrm{~g}$ of dry pulp. The relative increase in conversion after $48 \mathrm{~h}$ was calculated from the conversion difference between hydrolysis experiments with and without extract added to the (bleached) pulp. For comparison, the model protein BSA was added to the unbleached pulp. As demonstrated by Yang and Wyman (2006), the addition of BSA enhances enzymatic hydrolysis of cellulose. In the experiment with wheat straw pulp, it leads to a maximum conversion increase of $16 \%$ at $48 \mathrm{~h}$ using $250-500 \mathrm{mg}$ protein at an enzyme dose of $2.5 \mathrm{FPU} / \mathrm{g}$. Based on the amount of proteins added, the wheat straw extract shows a stronger promotional effect than BSA on the enzymatic digestibility of organosolv pulp. It is unclear whether the proteins differ from BSA in composition leading to a greater affinity for adsorption to lignin or have a larger amorphogenetic effect on the substrate. In addition, other nonprotein components larger than $1 \mathrm{kD}$ in the extract could play a role in both mechanisms. The delignified pulp having the largest relative conversion increase is partly due to substrate availability at $48 \mathrm{~h}$. In absolute values, the glucose yield increase is similar for the extract (0-228 $\mathrm{mg}$ protein added) and BSA addition (0$500 \mathrm{mg}$ protein added), i.e. $80.6-99.9 \%$ and $80.6-93.3 \%$ respectively. For the bleached pulp, the glucose yield is $62.6 \%$ when no extract is added, increasing to $87.1 \%$ when the extract contained $228 \mathrm{mg}$ of wheat straw proteins.

\subsubsection{Wheat straw pulp from other pretreatment processes}

Development of the organosolv technology towards applying milder process conditions and different solvents could impact pulp cellulose enzymatic digestibility. The effect of adding watersoluble extractives might be influenced by, for example, pulp residual lignin content and characteristics. Therefore, the promotional effect of water-soluble extractives on enzymatic hydrolysis of wheat straw pulp was also demonstrated for other organosolv processes, i.e. low-temperature acetone-based organosolv (Smit et al., 2015) and the acetic acid/formic-acid organosolv process of CIMV (Snelders et al., 2014). Additional delignification after organosolv treatment of the CIMV pulp resulted in a pulp with a very low lignin content (Snelders et al., 2014). In spite of this, glucose yield

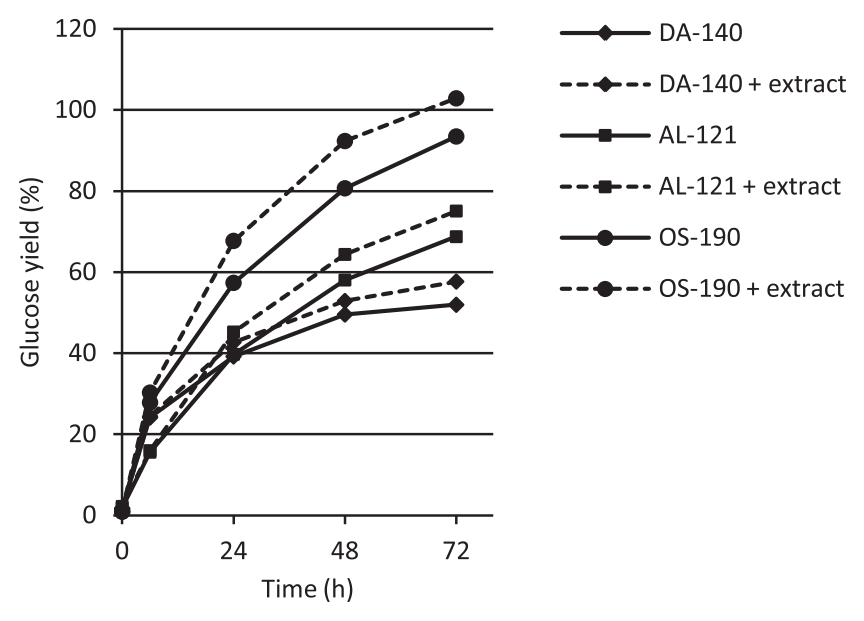

Fig. 4. Effect extract on enzymatic digestibility of organosolv, dilute acid and alkaline pretreated pulp using $2.5 \mathrm{FPU} / \mathrm{g}$ dry substrate.

upon addition of the extract increased from 68 to $78 \%$ after $72 \mathrm{~h}$. For the data we refer to the Supplementary Information.

As examples of non-organosolv pretreatment processes, dilute acid and alkaline pretreatment was applied on wheat straw. For the enzymatic hydrolysis of the dilute acid and alkaline pretreated pulps using an enzyme dose of $2.5 \mathrm{FPU} / \mathrm{g}$, the promotional effect of the wheat straw extract is comparable to what has been observed in case of organosolv pulp (Fig. 4). Generally, an increase in pulp glucan digestibility of about $10 \%$ is observed. Different temperature-acid dose combinations were applied for the dilute acid pretreatment of wheat straw in order to produce pulp substrates with similar yields, but potentially differing residual (pseudo-) lignin characteristics (Hu et al., 2013; Rahikainen et al., 2013). The differences observed in enzymatic digestibility are rather small, with a glucose yield of $52.0,57.3$ and $57.2 \%$ for the DA-140, DA-160 and DA-180 pulps, respectively. The relative increase in enzymatic digestibility upon addition of the extract was $11.0 \%$ (DA-140), 8.2\% (DA-160) and 6.8\% (DA-180). The extract effects have also been demonstrated for the enzymatic hydrolysis of alkaline pretreated pulps of which the final glucose yield increases from 68.8 to $75.1 \%$ (relative increase of 9.2\%). Although the relative increase is around $10 \%$ for all pretreated pulps at an enzyme dose of $2.5 \mathrm{FPU} / \mathrm{g}$, the effect is larger for organosolv pulp at similar levels of pulp glucan conversion. When comparing DA140 pulp (glucose yield: $52.0 \%$ using $2.5 \mathrm{FPU} / \mathrm{g}$ ) and organosolv pulp (glucose yield: $48.0 \%$ using $1.0 \mathrm{FPU} / \mathrm{g}$ ), the relative conversion increase is 11.0 and $50.6 \%$ respectively. The extract effect seems therefore not directly correlated to the amount of lignin present in the pulp but rather to depend on residual lignin characteristics and affinity for cellulase adsorption (Meng et al., 2016).

\subsubsection{Pulp from other herbaceous biomass}

Assuming proteins play a decisive role in the promotional effect on cellulose digestibility, the observed phenomenon would not be limited to wheat straw, but hold for herbaceous biomass in general. This was confirmed using rice straw (Smit and Huijgen, 2014) and corn stover. Addition of an aqueous extract from corn stover to the enzymatic hydrolysis of organosolv pretreated corn stover ( $20 \% \mathrm{w} / \mathrm{w}$ consistency) increased glucose yield based on total pulp weight from 40 to $46 \% \mathrm{w} / \mathrm{w}$. For the data we refer to the Supplementary Information.

\subsubsection{Extraction conditions}

The influence of the extraction temperature on the promotional effect on enzymatic cellulose digestibility was assessed. A negligi- 
ble influence of the extraction temperatures was observed in the range $25-50{ }^{\circ} \mathrm{C}$. However, the promotional effect declines when applying an extraction temperature of 75 and $100{ }^{\circ} \mathrm{C}$, which might be due to protein denaturation given the assumed role of proteins in the observed promotional effect.

In addition, the use of acid $(0.1 \mathrm{M} \mathrm{HCl})$, base $\left(0.1 \mathrm{M} \mathrm{Na}_{2} \mathrm{CO}_{3}\right)$ and salt $(0.5 \mathrm{M} \mathrm{NaCl})$ during extraction was explored to extract other classes of proteins than (only) the water-soluble proteins. The use of acid, base and salts did neither increase the promotional effect nor significantly eliminate it. For the data we refer to the Supplementary Information.

\section{Conclusions}

Water-soluble extractives from wheat straw can enhance the enzymatic hydrolysis of wheat straw pulp obtained by organosolv, dilute acid and alkaline pretreatment. The promotional effect of using the crude extract without purification has been demonstrated. The positive effect originates from extract components larger than $1 \mathrm{kD}$, supporting the hypothesis that proteins play an important role. Overall, this contribution demonstrates the positive effect that aqueous extractives can play on the enzymatic hydrolysis of pretreated lignocellulose. Thus, the required enzyme dose can be reduced resulting in lower production costs for $2 \mathrm{G}$ biofuels and bio-based chemicals.

\section{Acknowledgements}

This work was funded by the Netherlands Ministry of Economic Affairs as part of ECN's biomass research program. The authors thank DuPont Industrial Biosciences and Dr. B. BenjellounMlayah (CIMV, France) for kindly supplying the cellulase enzyme and the CIMV wheat straw pulp, respectively.

\section{Appendix A. Supplementary data}

Supplementary data associated with this article can be found, in the online version, at http://dx.doi.org/10.1016/j.biortech.2017.07. 072.

\section{References}

Akimkulova, A., Zhou, Y., Zhao, X., Liu, D., 2016. Improving the enzymatic hydrolysis of dilute acid pretreated wheat straw by metal ion blocking of non-productive cellulase adsorption on lignin. Bioresour. Technol. 208, 110-116.

Arantes, V., Saddler, J.N., 2010. Access to cellulose limits the efficiency of enzymatic hydrolysis: the role of amorphogenesis. Biotechnol. Biofuels 3, 4.

Borjesson, J., Engqvist, M., Sipos, B., Tjerneld, F., 2007. Effect of poly (ethylene glycol) on enzymatic hydrolysis and adsorption of cellulase enzymes to pretreated lignocellulose. Enzyme Microb. Technol. 41, 186-195.

Brethauer, S., Studer, M.H., Yang, B., Wyman, C.E., 2011. The effect of bovine serum albumin on batch and continuous enzymatic cellulose hydrolysis mixed by stirring or shaking. Bioresour. Technol. 102, 6295-6298.

Coughlan, M.P., 1985. The properties of fungal and bacterial cellulases with comment on their production and application. Genet. Eng. Biotechnol. J. 3, 39110.

Gao, D., Haarmeyer, C., Balan, V., Whitehead, T.A., Dale, B.E., Chundawat, S.P., 2014. Lignin triggers irreversible cellulase loss during pretreated lignocellulosic biomass saccharification. Biotechnol. Biofuels 7, 175.

Ghose, T.K., 1987. Measurement of cellulase activities. Pure Appl. Chem. 59, $257-$ 268.
Hall, M., Bansal, P., Lee, J.H., Realff, M.J., Bommarius, A.S., 2010. Cellulose crystallinity - a key predictor of the enzymatic hydrolysis rate. FEBS J. 277, 1571-1582.

Han, Y., Chen, H., 2007. Synergism between corn stover protein and cellulase. Enzyme Microb. Technol. 41, 638-645.

Han, Y., Chen, H., 2010. Synergism between hydrophobic proteins of corn stover and cellulase in lignocellulose hydrolysis. Biochem. Eng. J. 48, 218-224.

Hu, F., Jung, S., Ragaukas, A.J., 2013. Pseudo-lignin formation and its impact on enzymatic hydrolysis. Bioresour. Technol. 117, 7-12.

Huijgen, W.J.J., Reith, J.H., Den Uil, H., 2010. Pretreatment and fractionation of wheat straw by an acetone-based organosolv process. Ind. Eng. Chem. Res. 49, 10132 10140.

Huijgen, W.J.J., Smit, A.T., Reith, J.H., Den Uil, H., 2011. Catalytic organosolv fractionation of willow wood and wheat straw as pretreatment for enzymatic cellulose hydrolysis. J. Chem. Technol. Biotechnol. 86, 1428-1438.

Klein-Marcuschamer, D., Oleskowicz-Popiel, P., Simmons, B.A., Blanch, H.W., 2012. The challenge of enzyme cost in the production of lignocellulosic biofuels. Biotechnol. Bioeng. 109, 1083-1087.

Kristensen, J.B., Borjesson, J., Bruun, M.H., Tjerneld, F. Jorgensen, H., 2007. Use of surface active additives in enzymatic hydrolysis of wheat straw lignocellulose. Enzyme Microb. Technol. 40, 888-895.

Mansfield, S.D., Mooney, C., Saddler, J.N., 1999. Substrate and enzyme characteristics that limit cellulose hydrolysis. Biotechnol. Prog. 15, 804-816.

McIntosh, S., Vancov, T., 2011. Optimisation of dilute alkaline pretreatment for enzymatic saccharification of wheat straw. Biomass Bioenergy 35, 3094-3103.

Meng, X., Yoo, C.G., Li, M., Ragauskas, A.J., 2016. Physicochemical structural changes of cellulosic substrates during enzymatic saccharification. J. Appl. Biotechnol, Bioeng. 1, 00015.

National Renewable Energy Laboratory (NREL), 2009. Chemical analysis and testing laboratory analytical procedures. Golden, $\mathrm{CO}$.

Pan, X., Xie, D., Gilkes, N., Gregg, D.J., Saddler, J.N., 2005. Strategies to enhance the enzymatic hydrolysis of pretreated softwood with high residual lignin content. Twenty-Sixth Symposium on Biotechnology for Fuels and Chemicals, pp. 10691079.

Park, S., Baker, J.O., Himmel, M.E., Parilla, P.A., Johnson, D.K., 2010. Cellulose crystallinity index: measurement techniques and their impact on interpreting cellulase performance. Biotechnol. Biofuels 3, 10.

Rahikainen, J.L., Martin-Sampedro, R., Heikkinen, H., Rovio, S., Marjamaa, K., Tamminen, T., Rojas, O.J., Kruus, K., 2013. Inhibitory effect of lignin during cellulose bioconversion: the effect of lignin chemistry on non-productive enzyme adsorption. Bioresour. Technol. 133, 270-278.

Smit, A.T., Huijgen, W.J.J., 2014. Process for enzymatic hydrolysis of cellulose. Patent application WO2014098589.

Smit, A.T., Huijgen, W.J.J., Grisel, R.J.H., 2015. Improved process for the organosolv treatment of lignocellulosic biomass. Patent application WO 2015009145.

Snelders, J., Dornez, E., Benjelloun-Mlayah, B., Huijgen, W.J.J., De Wild, P.J., Gosselink, R.J.A., Gerritsma, J., Courtin, C.M., 2014. Biorefining of wheat straw using an acetic and formic acid based organosolv fractionation process. Bioresour. Technol. 156, 275-282.

Trajano, H.L., Engle, N.L., Foston, M., Ragauskas, A.J., Tschaplinski, T.J., Wyman, C.E., 2013. The fate of lignin during hydrothermal pretreatment. Biotechnol. Biofuels 6, 110.

Tu, M., Saddler, J.N., 2010. Potential enzyme cost reduction with the addition of surfactant during the hydrolysis of pretreated softwood. Appl. Biochem. Biotechnol. 161, 274-287.

Van Dyk, J.S., Pletschke, B.I., 2012. A review of lignocellulose bioconversion using enzymatic hydrolysis and synergistic cooperation between enzymes - factors affecting enzymes, conversion and synergy. Biotechnol. Adv. 30, 1458-1480.

Varnai, A., Siika-aho, M., Viikari, L., 2010. Restriction of the enzymatic hydrolysis of steam-pretreated spruce by lignin and hemicellulose. Enzyme Microb. Technol. 46, 185-193.

Wildschut, J., Smit, A.T., Reith, J.H., Huijgen, W.J.J., 2013. Ethanol-based organosolv fractionation of wheat straw for the production of lignin and enzymatically digestible cellulose. Bioresour. Technol. 135, 58-66.

Wyman, C.E., 2007. What is (and is not) vital to advancing cellulosic ethanol. Trends Biotechnol. 25, 153-157.

Yang, B., Wyman, C.E., 2006. BSA treatment to enhance enzymatic hydrolysis of cellulose in lignin containing substrates. Biotechnol. Bioeng. 94, 611-617.

Yang, Q., Pan, X., 2016. Correlation between lignin physicochemical properties and inhibition to enzymatic hydrolysis of cellulose. Biotechnol. Bioeng. 113, 12131224.

Yee, H.Y., Goodwin, J.F., 1973. Evaluation of some factors influencing the oToluidine reaction with glucose. Anal. Chem. 45, 2162-2165.

Zheng, Y., Pan, Z., Zhang, R., Wang, D., Jenkins, B., 2008. Non-ionic surfactants and non-catalytic protein treatment on enzymatic hydrolysis of pretreated creeping wild ryegrass. Appl. Biochem. Biotechnol. 146, 231-248. 


\section{ECN}

Westerduinweg 3

P.O. Box 1

1755 LE Petten

1755 LG Petten

The Netherlands

The Netherlands

$\mathrm{T}+31885154949$

$F+31885158338$

info@ecn.nl

www.ecn.nl 